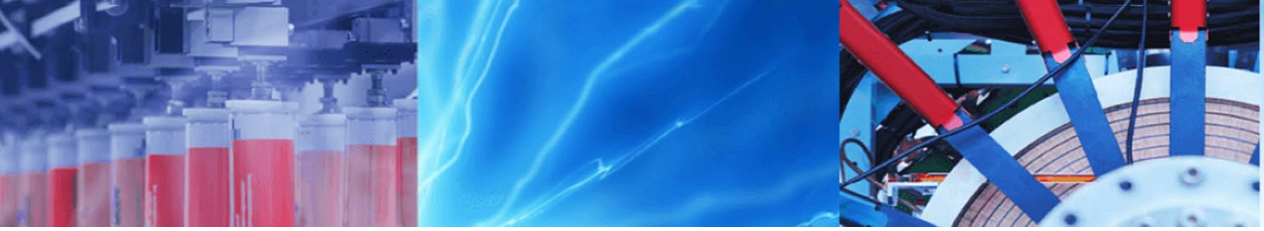

Research Article

\title{
Structural analysis and geophysical survey for hydrogeological diagnosis in uranium mine, Poços de Caldas (Brazil)
}

\author{
Débora Andrade Targa ${ }^{1}$. César Augusto Moreira ${ }^{1}$ Pedro Lemos Camarero ${ }^{1}$ Matheus Felipe Stanfoca Casagrande ${ }^{1}$. \\ Heber Luiz Caponi Alberti
}

(c) Springer Nature Switzerland AG 2019

\begin{abstract}
The implementation of open pit mines promotes alterations on geological and hydrogeological processes, mainly on natural streamflow patterns. Drainage system tries to reach its equilibrium due to modification on slope profiling water flows through new pathways contributing to erosion and leaching processes. One of the impacts related to mining is the generation of acid mine drainage (AMD), which occurs as a product of sulfide minerals exposure to oxidizing environment and, in contact to water, favors the formation of sulfuric acid. Thus, a low pH promotes a higher mobility of heavy metals and radionuclides, which become a source of contamination. In order to understand the hydrogeological dynamic in rock masses that contribute to AMD production, this paper aimed to subsidize mitigation programs in fractured aquifers using a structural analysis and geophysical survey for the reduction of acid drainage generation. The study was carried at the four mining fronts that compose the mine pit of Osamu Utsumi Mine, named according to its cardinal position (NE, SE, SW and NW). Local structural survey indicated that fractures attitudes are mainly N20E/80NW and N55 W/75NE, with intersections between them. Evidence of water flows, like whitish kaolinite stains and small vegetation growth, was identified in fronts NE, SW and NW, in addition to water springs at the base of the slopes. The flows arise mainly in areas that coincide to intersection between fracture systems in an orthogonal arrangement and the fracturing pattern indicated that at all fronts most of the fracture planes project into the open pit area, which favor the water channeling to the center of the mine as a water catchment basin. Moreover, the relationship between the persistence and spacing among the discontinuities enables a good hydraulic conductivity within the rock masses and the water upwelling on the slopes surface. The geophysical data corroborated with the structural survey, which identified the fracture planes as linear structures associated with low resistivity zones. DC resistivity method showed a strong contrast between saturated zones, differing natural from acidic water. Delimitation of linear features in the inversion models indicated that water flows are channeled through fracture planes and promote an expressive weathering process inside the rock masses, observed at depths of up to $70 \mathrm{~m}$.
\end{abstract}

Keywords Fractures $\cdot$ DC resistivity $\cdot$ Structural analysis $\cdot$ Hydrogeology

Débora Andrade Targa, debora.targa@gmail.com; César Augusto Moreira, moreirac@rc.unesp.br; Matheus Felipe Stanfoca Casagrande, mfs-casagrande@hotmail.com; Heber Luiz Caponi Alberti, heber@cnen.gov.br| ${ }^{1}$ Geosciences and Exact Sciences Institute (IGCE), São Paulo State University (UNESP), 24A Avenue, 1515, Bela Vista., Rio Claro, São Paulo State 13506-900, Brazil. ${ }^{2}$ Poços de Caldas Laboratory, National Nuclear Energy Commission-CNEN, Poços de Caldas-Andradas Road, km 13, Poços de Caldas, Minas Gerais State 37701-970, Brazil.

SN Applied Sciences (2019) 1:299 | https://doi.org/10.1007/s42452-019-0309-7

Received: 10 December 2018 / Accepted: 27 February 2019 / Published online: 4 March 2019 


\section{Introduction}

Mining activities promote disturbance on the natural environment, especially on ecological and hydrodynamic processes. The advance of excavations in open pit mines breaks the natural equilibrium between geological and hydrogeological processes due to groundwater level lowering, decantation ponds and modification of drainage patters according to a new morphological setting by the disposal of tailing piles. As drainage system tries to reach its equilibrium due to modification on slope profiling, water flows through new pathways in both surface and subsurface, contributing to erosion and leaching processes [1-3].

Uranium mines, as the Osamu Utsumi Mine in Poços de Caldas-Brazil, are often associated with metal sulfides, minerals formed in more reducing conditions. As the water flows through fracture systems along the rock masses, the sulfide minerals are exposed to a more oxidizing environment, which favors the generation of acid mine drainage [4-8]. This phenomenon is characterized by a decreasing on $\mathrm{pH}$ due to $\mathrm{S}^{-2}$ oxidation into $\mathrm{SO}_{4}^{-2}$, whose contact with water produces sulfuric acid and, hence, increases the mobility of heavy metals $(\mathrm{Cu}$, $\mathrm{Ni}, \mathrm{Cd}, \mathrm{U}, \mathrm{Mn}$ and $\mathrm{Zn}$ ) and radioactive elements sourced from rock masses and/or tailing piles [9-11]. In addition, these contaminates could easily be carried toward the drainage system near the mining complex, with direct impacts on the surface streams and groundwater system.

The concern about environmental liabilities in mining complexes has increased since the environmental laws became more rigorous and, thus, mineral prospecting techniques have been adapted as an alternative to mitigate these impacts. Conventional tools, like drillings and chemical analysis, require a high sampling density to obtain reliable results at heterogeneous geological areas. However, these methods increase operating costs and sometimes mitigation of damaged areas is unfeasible. On the other hand, indirect methods, as geophysics, have guaranteed excellent results in large-scale mapping of features with contrast of physical properties [12-14].

Properties like electrical resistivity, chargeability and dielectric constant are parameters correlated with hydrogeological and geochemical aspects and, therefore, they are widely applied to environmental investigations [15-18], groundwater contamination studies [19-21], generation of leaching in uncontrolled landfills [22-24] and generation of acid mine drainage $[14,25,26]$.

DC resistivity is a geophysical method that has contributed to hydrogeological studies in order to understand geochemical processes responsible for acid mine drainage and to propose solutions in detailed scale. Its application in fractured rock masses has provided good results in the identification of fractures and faults systems, whose spatial distribution favors groundwater percolation and, hence, sulfides leaching and environmental acidity. However, at structurally controlled areas, the acquisition of geophysical data requires a proper arrangement based on structural survey in order to identify physical properties contrast between rocks and saturated zones with acid drainage.

Structural survey is an essential tool to recognize discontinuities that favor groundwater percolation within rock masses and eventual water springs that result in water accumulation in the mine pit. Huge volume of acid mine drainage demands continuous pumping and high treatment costs even after the mine decommissioning, whose procedures increase expenses to mitigate environmental liabilities. Therefore, this paper aims to subsidize mitigation programs in fractured aquifer using structural survey and $D C$ resistivity method to identify discontinuities with higher potential of water percolation in order to reduce water springs and the generation of acid drainage.

\section{Study area and operational history}

The Poços de Caldas mining site is located in Minas Gerais State, about $20 \mathrm{~km}$ south from Poços de Caldas-MG and $220 \mathrm{~km}$ north from São Paulo—SP, which is the largest city in the country. The mining complex occupies an area of about $15 \mathrm{~km}^{2}$ and represents the first site to explore uranium ore in Brazil, whose operation is under Nuclear Industries of Brazil (INB - Indústrias Nucleares do Brasil) responsibility (Fig. 1).

The discovery of promising caldasite deposits, a mixture of zircon and baddeleyite, provided conditions to implement the Osamu Utsumi Mine in 1959, when mineralized zones with uranium ores were found [27]. Operational activities started in 1981 as an open pit mine and, after 15 years, the uranium mining and milling operations have ceased. Its mineral reserve was approximately 17.200 tons of $\mathrm{U}_{3} \mathrm{O}_{8}$, with an annual production of 500 tons [28-30]. The uranium ore grade varied from 675 to $1705 \mathrm{ppm}$, whose deposit was considered as low grade associated with primary mineralization of $Z r$ rare earth elements and a secondary mineralization caused by hydrothermal processes [29]. Ore grade lower than 170 ppm corresponds to waste rock, and it is not economically explored.

Nowadays, the Osamu Utsumi Mine is at the decommissioning stage, looking forward to reduce the consequences of environment impacts. INB established a compromise with IBAMA, CNEN (National Commission of Nuclear Energy) and FEAM (Environment State Foundation of Minas Gerais) to present a project to manage the degraded area. The 


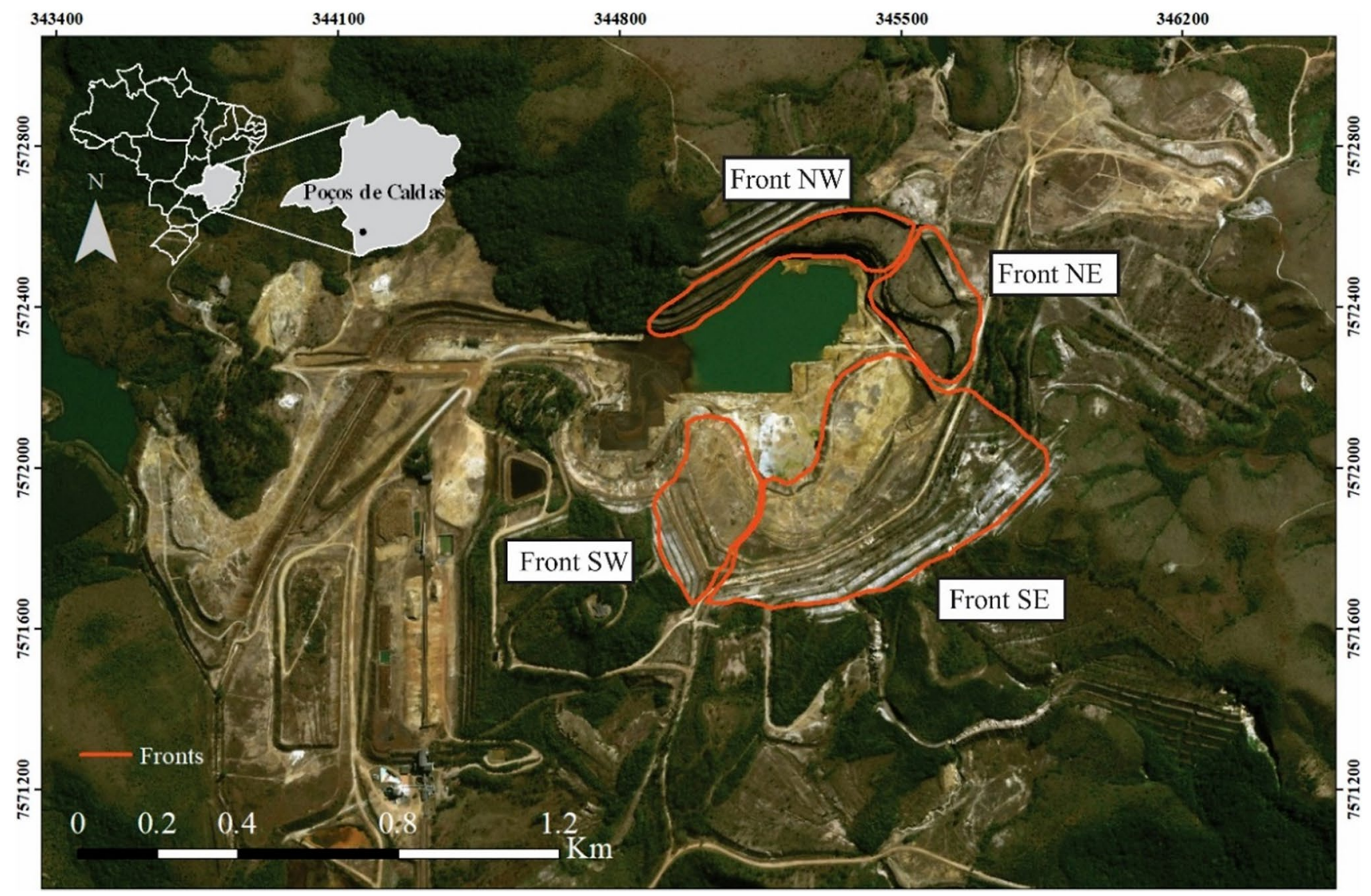

Fig. 1 Study area location and the four fronts submitted to structural and geophysical surveys

operations gave rise to two main sources of contaminants to the environment, the waste rock piles $\left(4.48 \times 10^{7} \mathrm{~m}^{3}\right)$ and the tailing dam $\left(2.39 \times 10^{6} \mathrm{~m}^{3}\right)$ [31-33]. These materials in contact with water provided conditions to generate acid mine drainage, characterized by low $\mathrm{pH}$ and radioactive elements and heavy metals enrichment [34].

The open pit is located between the two main waste rock piles of Osamu Utsumi Mine, responsible for a considerable volume of acid drainage pumped to treatment stations. It is possible that part of the water that reaches the open pit infiltrates into the waste material, contributing to the water supply inside this geological material and, hence, favoring the interaction between water and sulfide zones to produce acid effluents. Therefore, understanding the hydrogeological context of the rock mass in the open pit mine is important to control one of the sources of water that feeds the acid drainage of the waste piles.

\section{Materials and methods}

The study area corresponds to the Osamu Utsumi Mine, being part of the Mesozoic Poços de Caldas alkaline complex, the largest known in South America $[35,36]$. The mine pit has an elliptical shape, with dimensions of $1200 \mathrm{~m} \times 800 \mathrm{~m}$ and depth of $200 \mathrm{~m}[28,33]$.

Structural analysis was divided into two steps. The first one consisted of extraction of structural features at regional scale from aerial images of Google Earth Pro, which were digitalized by ArcGis 10.3 software. This product allowed the identification of regional discontinuity trends and a possible correlation with local structural setting. The second one corresponded to structural survey of fracture planes in rock masses along the four mining fronts that compose the mine pit, named 
according to its cardinal position (NE, SE, SW and NW). A Bruton compass and Clar notation (dip direction/dip) provided the structural measures, whose local magnetic declination is $21^{\circ} 37^{\prime}$ [37-39].

Structural survey obtained 755 measures of fracture planes from the four mining fronts and the presence of water flow along discontinuities were also documented (Fig. 2). It is important to notice that the data were acquired during dry season, which could interfere in the volume of water that reaches the mine pit. At front SE, 255 fracture planes were measured at three bench levels, while each one of the other fronts provided 150 discontinuity measures along the lowest bench level near the lake. The data were organized in txt files to compose frequency diagrams using Openstereo Software, whose full circles showed a better distribution of discontinuities strike and dip direction.

The geophysical method chosen for this study was DC resistivity, which determines the apparent resistivity of geological materials at variable depths. The resistivity method is based on measuring the potentials between one pair of electrodes while transmitting direct current between another pair of electrodes. The depth of penetration is proportional to the distance between the electrodes, in homogeneous ground, and varying the electrode separation provides information about the underground stratification [40-42].

Ohm's law enables to perform apparent resistivity $\left(\rho_{\mathrm{a}}\right)$ calculations in a heterogeneous geological environment considering a geometric factor $(K)$ between two pairs of electrodes used to acquire the data, namely voltage $(\Delta V)$ (electrodes $A$ and $B$ ) and the intensity of electric current (I) (electrodes $C$ and $D$ ). Thus, it is possible to determine the existence of mineralization and to recognize geological structures in subsurface [43]. Equations 1 and 2 summarize the relationship between the physical parameters described:

$\rho_{\mathrm{a}}=\frac{K \times \Delta V}{l}$

$K=2 \pi+\left(\frac{1}{\mathrm{AC}}-\frac{1}{\mathrm{CB}}-\frac{1}{\mathrm{AD}}+\frac{1}{\mathrm{DB}}\right)^{-1}$

where $A C, C B, A D$ and $D B$ are the distances between electrodes.
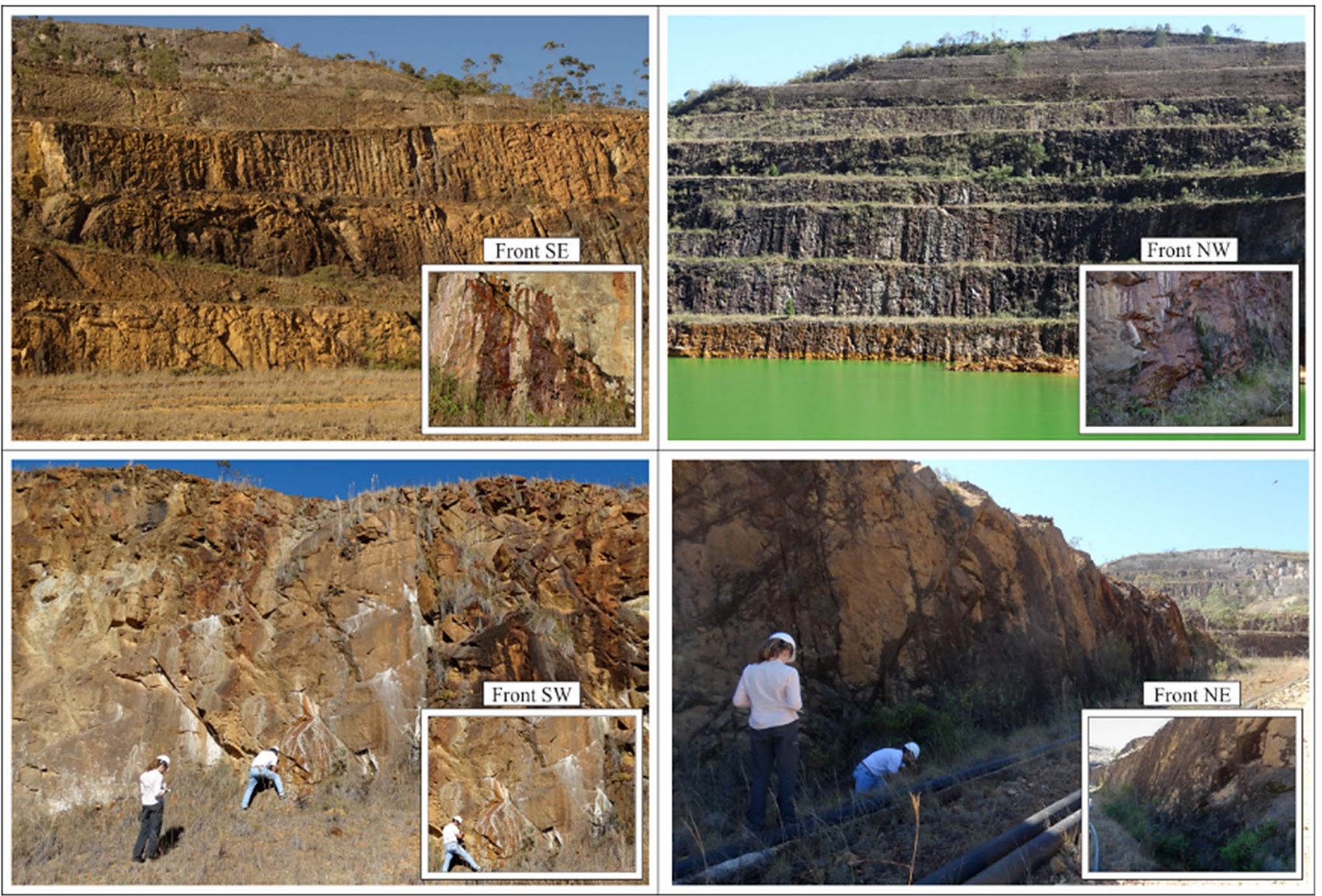

Fig. 2 Main evidence of water percolation at the four fronts, represented by water strings and whitish kaolinite stains

\section{SN Applied Sciences}


Geophysical data were acquired along four lines arranged one on each front, using the electrical tomography technique and Schlumberger array. At front NE, it was not possible to obtain a reliable geophysical data from a line parallel to its slopes due to extremely dry conditions of the geological material. In this case, the study considered the closest line to NE, located at front SE.

The equipment used was an ABEM Terrameter LS resistivity meter with 84 channels and $250 \mathrm{~W}$ of power, which is calibrated for resistivity measurements through periodic cycles of electric current at low frequency, a procedure that allows filtering the acquired signal noise [44].

Res2Dinv (Geotomo Software) has been chosen as a data processing and inversion software once it is widely available and very popular in geophysical studies. This software is designed to interpolate and invert field data of electrical geophysical prospecting according to the mathematical model of ordinary least squares (OLS). This technique is responsible for smoothing the extreme values using a block modeling and, hence, reduces differences between the resistivity measured and the resistivity modeled. Block modeling generates a standard deviation parameter called root-mean-squared (RMS) factor that represents mainly the match between the calculated pseudosection and that obtained in the field, influenced by the presence of extreme values in the input data, potentialized by postprocessing $[45,46]$. The local topography is inserted into the model to avoid possible distortions on the resulting cross section. Resulting resistivity models are presented as $2 \mathrm{D}$ colored sections with resistivity in a chromatic scale range defined in order to better analyze the results and to identify contrasts between different geological materials.

The integration between structural survey and geophysical data made possible a hydrogeological diagnosis of Osamu Utsumi Mine, aiming to identify fracture zones that favor water percolation and contribute to acid mine drainage process.

\section{Results and discussion}

Regional structural setting showed two main fracture systems, whose directions are NE-SW and NW-SE (Fig. 3). The fractures tend to follow the circular edges of the Poços de Caldas alkaline complex. This setting is an evidence of the circular and radial cracks that allowed the ascent of nepheline magma and the formation of an almost complete annelar dyke [33, 36, 47-50].

On the northwest portion of the alkaline complex, near Poços de Caldas city, regional fractures show a trend to NE-SW. On southeast side, it is possible to notice an intersection between two fracture systems, with a trend to NE and NW, almost orthogonal to each other, a pattern also observed near the Osamu Utsumi Mine. Another feature that highlights the regional fracture
Fig. 3 Main regional fracture systems identified along the alkaline complex and their correlation to watershed drainage pattern

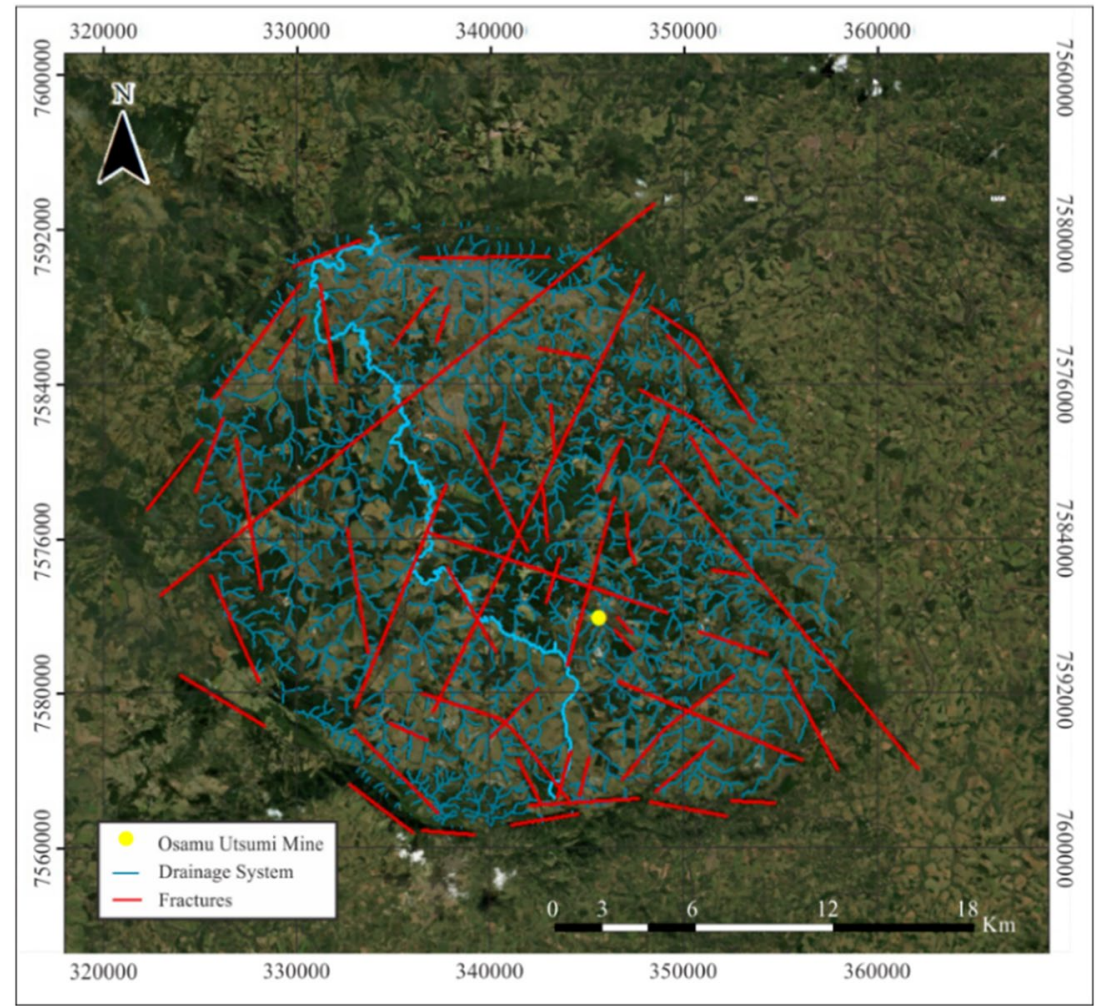

SN Applied Sciences A SPRINGER NATURE journal 
system is the Antas River drainage pattern, where river flows from southeast to northwest with streams at almost right angles to NE and then to NW.

The fronts that compose the Osamu Utsumi Mine were built using bench system with each bench comprising $7 \mathrm{~m}$ width and rocky slopes with $12 \mathrm{~m}$ length and $70^{\circ}$. The slopes are mainly composed by phonolites and nepheline syenites. Evidence of water flows comprises whitish kaolinite stains and small vegetation growth, identified in fronts NE, SW and NW, in addition to water springs at the base of the slopes (Fig. 2). The predominance of kaolinite stains is due to the fact that fieldwork was carried out during dry season with low water supply into the rock mass. Fronts SE and NW present water streams that continuously flow toward the open pit and then they are pumped to treatment stations. The flows arise mainly in areas where fracture systems are in an orthogonal arrangement. Even though front SE receives a high incidence of sunlight during most part of the day, factor that would probably contribute to increase water evaporation at the slope surfaces, the volume of water originated from the slopes is significantly larger compared to front NW, where there is practically no incidence of sunlight.

Local structural survey shows that fractures attitudes are mainly N20E/80NW and N55W/75NE, with intersections between them. The slope of front SE presents a strike to NE-SW with dip direction to NW and angle superior to $80^{\circ}$. The mean fractures attitude is N25E/75NW. The slope of front NW has a trend NE-SW and dip direction to SE. The main structures are represented by fracture planes with two preferable attitudes: N85E/75SE and N35E/75NW. Slopes at front SW have a NW-SE strike with dip direction to NE. This front shows two main fracture systems, with average attitude of N55W/85NE and N25E/65SE. On these three fronts, the discontinuities are parallel to the slopes with dipping concordant to the slopes face, whose structural setting favors the channeling of water flow toward the open pit area. Slopes at front NE present a strike to NW-SE with dip direction to SW. The mean fracture planes attitude is N5E/85NW. The structural setting of this front indicates that discontinuity attitude and slope direction are not parallel, which implies in reducing the channeling of water flows toward the surface.

The local fracture pattern is the same as that identified by Scudino [51], which determined a preferential orientation of N55-60W/90 and N30-45E/90 for the regional structural setting of alkaline complex of Poços de Caldas, whose NW trend would be related to the geological basement and NE trend to the volcanic system. Figure 4 illustrates the main structural trend of the fronts and the geophysical tomography lines used, whose end is indicated by the blue arrows.
The correlation between local and regional fracturing patterns allows to state that these discontinuities present in the Osamu Utsumi Mine are derived from volcanic activities [51]. The opening of the pit and mining operation involved the dismantling of the rock mass by the use of explosives, a technical procedure planned for rock fragmentation in dimensions that allow its transportation and optimizes the use of crushers and mills in the process of ore concentration. The energy released during detonations amplifies the existing structural arrangement in terms of continuity and connectivity of fractures and creating new ones. This peculiar aspect provides a structural framework that potentiates the underground flow both in the preexisting system and in the secondary one $[52,53]$.

It was observed a strong structural control of the drainage network, whose channels flow from the southeast toward the northwest portion, a result compatible with those presented by Waber et al. [54]. By correlating the regional fracture zones and the alignment of drainage, it is suggested that these structures are capable of directing the water flows near the open pit area. Local discontinuities are fundamental in the diffusion of the underground flow.

This structural configuration is consistent with data obtained by the fracture planes survey at the Osamu Utsumi Mine, with NE-SW direction and dip direction to NW. Then, this allows to state that the water flowing through the fractures are channeled preferentially to NW and is transported by the watershed of Antas River toward Poços de Caldas and Águas da Prata cities.

At local scale, the fracturing pattern indicated that at all fronts most of the fracture planes project into the open pit area, which favor the water channeling to the center of the mine as a water catchment basin (Fig. 4). The fracture systems intercept each other and provide channels that dive toward the open pit, where it is possible to observe water springs. Discontinuities with NW trend are essential for the water circulation inside the rock masses, since they are responsible for the constant supply of the watershed of Antas River [55, 56].

The mere existence of fracture system along the rock mass is insufficient to justify the constant water springs from the fronts. Discontinuities must be spatially distributed and connected in order to provide hydraulic conditions to underground water flowing through the fracture planes. Thus, their persistence must be greater than their spacing to allow a good hydraulic conductivity inside the rock mass [57].

Persistence is represented by the horizontal and vertical extension of fractures, while spacing consists of the mean distance between the fracture planes and it can be classified according to its density. The fractures along the Osamu Utsumi Mine present great vertical and horizontal 


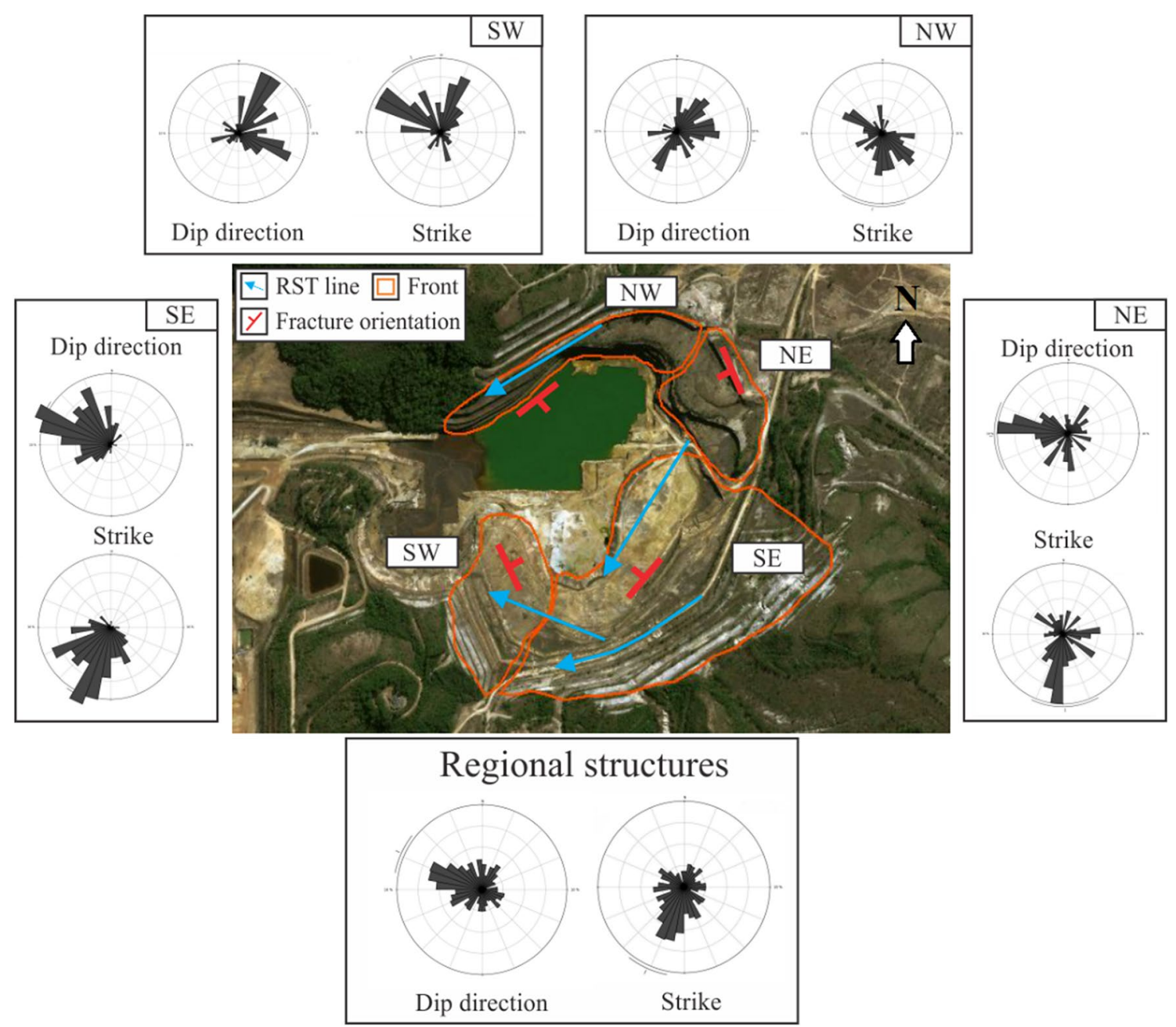

Fig. 4 Structural analysis of the Osamu Utsumi Mine fronts, highlighting the main orientation of discontinuities and the orientation of geophysical tomography lines

continuity [58], which is observed at successive benches levels and connected to slopes surface. The average distance between fracture planes comprises an interval of 1 to $3 \mathrm{~m}$, which characterizes the fronts with very far distance between fractures and sparsely distributed [58, 59]. The relationship between the two parameters favors a good hydraulic conductivity within the rock masses at Osamu Utsumi Mine and the water springs on the slopes surface, especially on the fronts SE, SW and NW.

Inversion models produced from the geophysical data processing indicate zones of low resistivity, which can be related to water percolation zones inside the rock mass (Fig. 5). These zones are characterized by resistivity values from 1 to $40 \Omega \mathrm{m}$ and 40 to $130 \Omega \mathrm{m}$, which are less resistive than the background rock which has high resistivity (values higher than $400 \Omega \mathrm{m}$ ).

Preliminary studies based on the historical chemical analysis of the local groundwater confirm the existence of acid mine drainage at particular areas of the aquifer [33, 56]. The resistivity values between 1 and $40 \Omega \mathrm{m}$ might be related to high salinity in acid mine drainage flows, caused by sulfides oxidation and acidification and dissolution of metals within the rock mass. The increase in salinity in aquifers due to contribution of pollutants is characterized by expressive decrease in the resistivity values when compared to natural streams [60-63].

Areas with resistivity values between 40 and $130 \Omega \mathrm{m}$ indicate streams with lower salinity associated with a natural or uncontaminated groundwater flow, which is predominant in the study area and also recognized in preliminary geochemical studies [56]. Values between 400 and $5000 \Omega \mathrm{m}$ show rocks with variable weathering stages, while higher values of resistivity $(>5000 \Omega \mathrm{m}$ ) are correlated with unsaturated and unaltered rocks.

Fracture planes are easily identified as linear structures associated with low resistivity zones that reach 

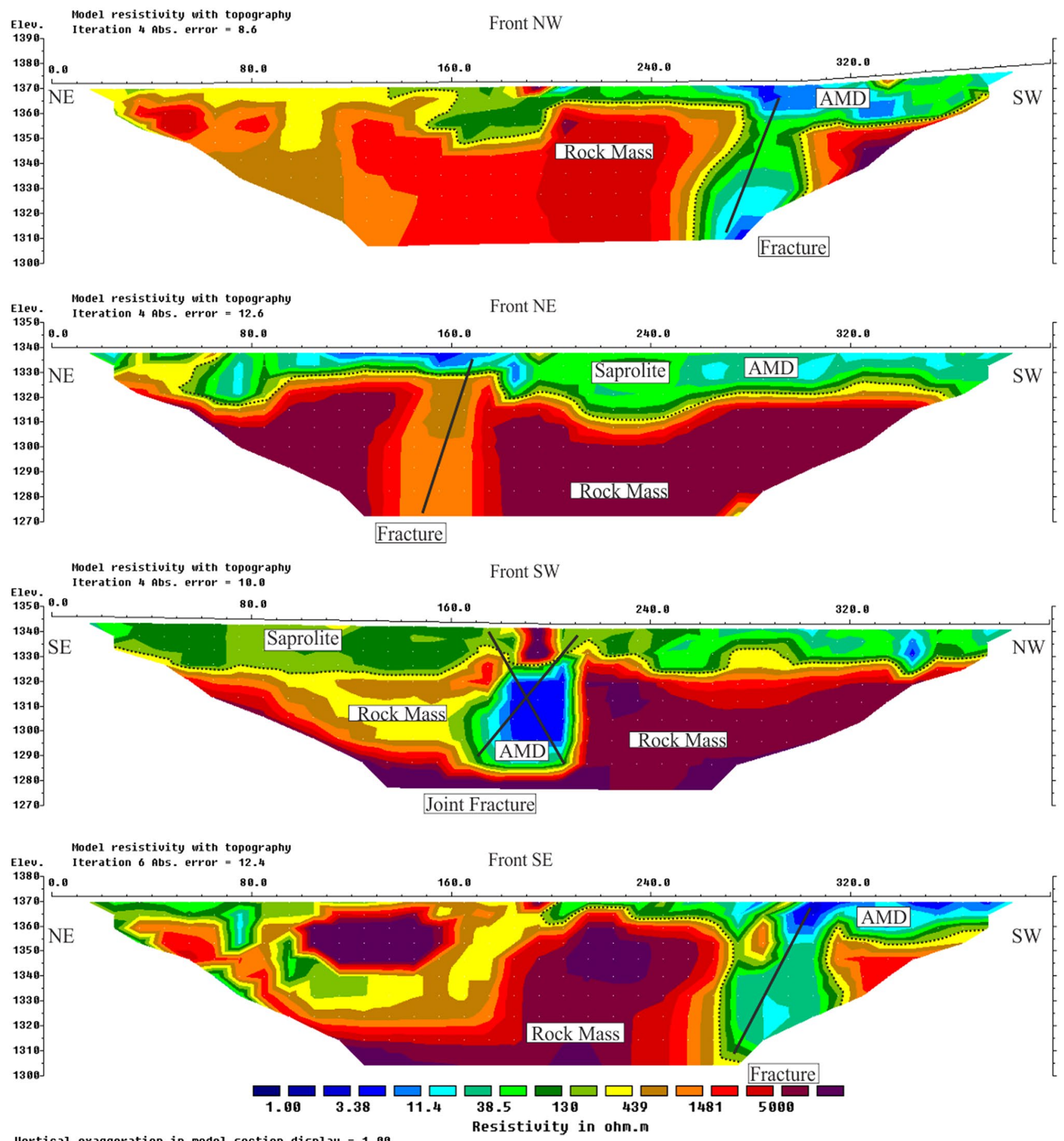

Vertical exaggeration in model section display $=1.00$ First electrode is located at $0.0 \mathrm{n}$.

Last electrode is located at $400.0 \mathrm{~m}$.

Fig. 5 Resistivity inversion models highlighting linear structures with low resistivity values at each front

about $70 \mathrm{~m}$ of depth. This fact corroborates the existence of water percolation inside the rock mass and, consequently, promoting its intense weathering and disintegration. The intersection between fracture planes was also identified by DC resistivity method and reflects the discontinuity pattern described at the slope surface, as seen in front SW' section. Figure 6 illustrates the main geological and hydrogeological features that have a good correlation with the main geophysical features present in the resistivity models, especially the superficial water springs and low resistivity zones. 

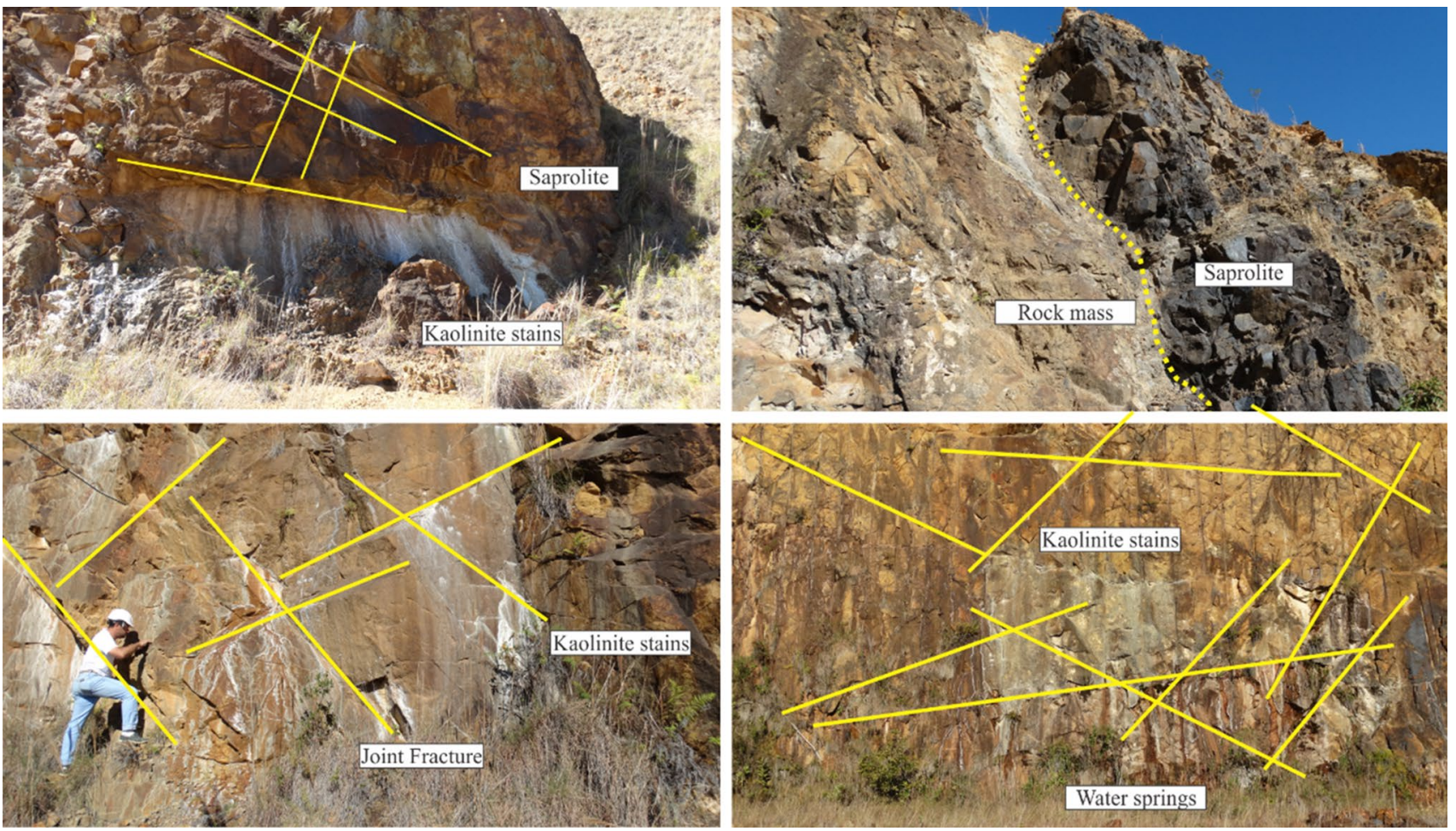

Fig. 6 Main geological features that have a good correlation with the geophysical inversion models

The water flows from fronts SE, SW and NW are channeled through the Cercado Stream and flow toward the Antas River. On the other hand, front NE presents no evidence of water percolation in the rock mass. The absence of evidence is attributed to the fact that front NE is located in a watershed divisor, whose fractures present a dip direction to west and, hence, contribute to a greater water supply toward the front NW, where it is possible to observe a continuous water spring $[28,33]$. The resistivity section of front NW indicates the presence of a low resistivity zone at its eastern portion near the surface, possibly associated with the water flow that migrates from front NE to front $\mathrm{NW}$ and is channeled to depths of $40 \mathrm{~m}$ to $70 \mathrm{~m}$. Moreover, drainage near front NE is part of the Consulta Stream system, responsible for channeling the waters at the northeast portion of the mine pit toward the Verde River.

Intense water percolation inside the rock mass gradually compromises their physical integrity, with loss of cohesion and fragmentation. This scenario is observed in advanced weathered zones of the mining fronts, where the rocks were altered to friable soils with hydrated minerals and intense mobilization of incompatible elements, like sulfides and radioactive elements. The increase in sulfur in the groundwater causes a drop in $\mathrm{pH}$, which provides conditions to increase the solubilization of heavy metals and radioactive elements. As a result, these acid effluents with high ionic concentration are conducted toward the slopes face, resulting in punctual acid drainage at the base of mine pit $[64,65]$.

Thus, the origin of acid mine drainage is linked with the weathering process inside the rock mass and groundwater acidification by constant water percolation and sulfide oxidation. The generation of acidic water enriched in heavy metals and radioactive elements implies a daily treatment of the open pit area water, in an attempt to maintain the volume of effluent and to restrict the environmental liabilities only to the open pit mine. Then, the surplus water must be properly treated to be launched in the region's drainage system.

\section{Conclusions}

The regional and local structural survey of rock masses was an essential tool to define the main fracture systems related to the water supply toward the open pit of Osamu Utsumi Mine. Apparently, there are conducive paths that enable water percolation along the fractured rock masses, whose discontinuities are associated with the structural setting of the basement and to successive blastings during the mining operation.

Clear evidence of water springs is observed at fronts $\mathrm{SE}, \mathrm{SW}$ and NW. There is no water spring at front NE possibly due to its location at watershed divisor. The main 
fracture systems have a preferred strike to NE-SW with dip direction to NW and strike to NW-SE with dip direction both for NE and SW, whose local structural setting is compatible with the regional structural context. The relationship between persistence and a regular distribution of discontinuities provided an excellent hydraulic conductivity inside the rock mass with water springs in the slopes surface.

There are fractures that naturally contribute to water flows toward the open pit area, whose discontinuity opening provided a pressure relief inside the rock mass and, hence, an expansion and connection between fractures. Therefore, there was an alteration in the aquifer hydraulic gradient and eventual increase in the water volume that flows to the bench base. This information enabled planning the geophysical data acquisition, with the proper settlement of the geophysical lines and the correlation between superficial features with their subsurface correspondents.

DC resistivity method showed a strong contrast between saturated zones, those due to natural streams from those due to acid effluents. Delimitation of linear features in the resistivity models indicates that water flows are channeled through fracture planes and promote an expressive weathering and leaching processes inside the rock mass, observed at depths of up to $70 \mathrm{~m}$. The method presented great sensitivity in the recognition of underground flows and saturated zones, factors that contribute to acid mine drainage process. Therefore, the integration between geochemical analysis from previous studies and the geophysical data acquired at Osamu Utsumi Mine provided conditions to establish a reliable hydrogeological diagnosis.

To mitigate environmental impacts generated by acid mine drainage geophysical methods should be used for detailed studies, in order to recognize areas that generate AMD for eventual treatment at specific zones. The suggested treatment comprises the isolation of sulfite zones from underground water percolation, sealing discontinuities close to sulfide minerals concentration or diverting local water flows at specific areas of the rock mass, in an attempt to hinder the sulfide oxidation process. As underground water flow is natural, constant and unavoidable, the study provides tools not to divert all the water flows from the rock mass but to identify sulfide zones and to avoid their contact to underground water.

Acknowledgements The authors are thankful to Applied Geology Department at São Paulo State University, Rio Claro-SP, for the technical support and to Nuclear Industries of Brazil for the access to the study area and human resource during fieldwork, especially to Thiago Fernando de Ávila Navarro and Amália Eugênia Matavelli Rosa.

\section{Compliance with ethical standards}

Conflict of interest On behalf of all authors, the corresponding author states that there is no conflict of interest.

\section{References}

1. Holmes DC, Pitty AE, Noy DJ (1992) Geomorphological and hydrogeological features of the Poços de Caldas caldera analogue study sites. J Geochem Explor 45:215-247

2. Rostirolla SP, Mancini F, Neto JMR, Figueira EG, Araújo EC (2002) Análise estrutural da Mina de Vazante e adjacências: geometria, cinemática e implicações para a hidrogeologia. Revista Brasileira de Geociências 32(1):59-68

3. Reis RC (2010) Estudo de estabilidade de taludes da mina de Tapira-MG. MSc Dissertation, Escola de Minas de Ouro Preto, MG, $\mathrm{p} 145$

4. Borma LS, Soares PSM (2002) Drenagem ácida e gestão de resíduos sólidos de mineração. In:Trindade RBM, Filho OB (eds) Extração de ouro: princípios, tecnologias e meio ambiente. CETEM/MCT, pp 253-276

5. Johnson DB, Hallberg KB (2005) Acid mine drainage remediation options: a review. Sci Total Environ 338:3-14

6. Simate GS, Ndlovu S (2014) Acid mine drainage: challenges and opportunities. J Environ Chem Eng 2:1786-1803

7. Nordstrom DK, Blowes DW, Ptacek CJ (2015) Hydrogeochemistry and microbiology of mine drainage: an update. Appl Geochem 57:3-16

8. Moyé J, Picard-Lesteven T, Zouhri L, Amari KE, Hibti M, Benkaddour A (2017) Groundwater assessment and environmental impact in the abandoned mine of Kettara (Morocco). Environ Pollut 231:899-907

9. Luz AB, Sampaio JA (2015) Desativação de Minas. Série tecnológica ambiental. Rio de Janeiro: CETEM/MCTI, p 50

10. Abrosimova N, Gaskova O, Loshkareva A, Edelev A, Bortnikova S (2015) Assessment of the acid mine drainage potential of waste rocks at the Ak-Sug porphyry Cu-Mo deposit. J Geochem Explor 157:1-14

11. Rybnikov PA, Rybnikova LS (2017) Formation of waste-rock drainage water on massive sulfide deposits of the Urals (Russia). Proc Earth Planet Sci 17:857-860

12. Baumgartner F, Christensen NB (1998) Analysis and application of a non-conventional underwater geoelectrical method in Lake Geneva, Switzerland. Geophys Prospect 46:527-541

13. Gélis $C$, Revil $A$, Cushing $M E$, Jougnot $D$, Lemeille F, Cabrera J, de Hoyos A, Rocher M (2010) Potential of electrical resistivity tomography to detect fault zones in limestones and argillaceous Formations in the experimental platform of Tournemire, France. Pure appl Geophys 167:1405-1418

14. Power C, Tsourlos $P$, Ramasamy $M$, Nivorlis $A$, Mkandawire $M$ (2018) Combined DC resistivity and induced polarization (DC-IP) for mapping the internal composition of a mine waste rock pile in Nova Scotia, Canada. J Appl Geophys 150:40-51

15. Silva JE, Loureiro EML, Elis VR, Hiodo FY, Porsani JL (2002) Aplicação de ensaios elétricos e eletromagnéticos em problema de poluição ambiental. Revista Brasileira de Geofísica 20:193-198

16. Revil A, Karaoulis M, Johnson T, Kemna A (2012) Review: some low-frequency electrical methods for subsurface characterization and monitoring in hydrogeology. Hydrogeol $J$ 20:617-658

17. Binley A, Hubbard SS, Huisman JA, Revil A, Robinson DA, Singha K, Slater LD (2015) The emergence of hydrogeophysics for improved understanding of subsurface processes over multiple scales. Water Resour Res 51:3837-3866 
18. Khalil AM, Bobst A, Mosolf J (2018) Utilizing 2D electrical resistivity tomography and very low frequency electromagnetics to investigate the hydrogeology of natural cold springs near Virginia city, Southwest Montana. Pure appl Geophys 175:3525-3538. https://doi.org/10.1007/s00024-018-1865-2

19. Yogeshwar P, Tezkan B, Israil M, Candasayar ME (2012) Groundwater contamination in the Roorkee area, India: 2D joint inversion of radiomagnetotelluric and direct current resistivity data. J Appl Geophys 76:127-135

20. Mogaji KA (2017) Development of AHPDST vulnerability indexing model for groundwater vulnerability assessment using hydrogeophysical derived parameters and GIS application. Pure Appl Geophys 174:1787-1813. https://doi.org/10.1007/ s00024-017-1499-9

21. Sparrenbom CJ, Akesson S, Johansson S, Hagerberg D, Dahlin T (2016) Investigation of chlorinated solvent pollution with resistivity and induced polarization. Sci Total Environ 575:767-778

22. Meju MA (2000) Geoelectrical investigation of old/abandoned, covered landfill sites in urban areas: model development with a genetic diagnosis approach. J Appl Geophys 44:115-150

23. Park S, Yi MJ, Kim JH, Shin SW (2016) Electrical resistivity imaging (ERI) monitoring for groundwater contamination in an uncontrolled landfill, South Korea. J Appl Geophys 135:1-7

24. Maurya PK, Ronde VK, Fiandaca G, Balbarini N, Auken E, Bjerg PL, Christiansen AV (2017) Detailed landfill leachate plume mapping using 2D and 3D electrical resistivity tomography: with correlation to ionic strength measured in screens. J Appl Geophys 138:1-8

25. Yuval DWO (1996) DC resistivity and IP methods in acid mine drainage problems: results from the Copper Cliff mine tailings impoundments. J Appl Geophys 34:187-198

26. Poisson J, Chouteau M, Aubertin M, Campos D (2009) Geophysical experiments to image the shallow internal structure and the moisture distribution of a mine waste rock pile. J Appl Geophys 67:179-192

27. Maciel AC (2007) Formação de geólogos no Brasil e sua influência na prospecção, pesquisa e descoberta de jazidas de urânio. In: Gomes CB (org.). Geologia USP, 50 anos. Editora USP, São Paulo, p 544

28. Fraenkel MO, Santos RC, Loureiro FEVL, Muniz WS (1985) Jazida de urânio no Planalto de Poços de Caldas-Minas Gerais. Principais depósitos minerais do Brasil, v. 1, Recursos Minerais Energéticos, MME, DNPM e CVRD, Brasília, pp 89-103

29. Fernandes HM, Franklin MR, Gomiero LA (2008) Critical analysis of the waste management performance of two uranium production units in Brazil, Part I: Poços de Caldas production centre. J Environ Manag 87:59-72

30. Souza AM, Silveira CS, Pereira RM (2013) Contribuições dos metais provenientes das pilhas de rejeito da Mina Osamu Utsumi a drenagens do complexo Alcalino de Poços de Caldas, Minas Gerais. Geochimica Brasiliensis 27(1):63-76

31. Urânio do Brasil SA (1988) Síntese dos trabalhos-Gerência da Mina de Caldas. Relatório Interno, Urânio do Brasil. Poços de Caldas

32. Majdalani AA, Tavares AM (2001) Status of uranium in Brazil. IAEA-TECDOC 1258, IAEA, Vienna, pp 119-127

33. Franklin MR (2007) Modelagem numérica do escoamento hidrológico e dos processos geoquímicos aplicados à previsão da drenagem ácida em uma pilha de estéril da mina de urânio de Poços de Caldas, MG. 2007. Ph.D. Thesis, Universidade Federal do Rio de Janeiro, Rio de Janeiro, p 358

34. Akcil A, Koldas $S$ (2006) Acid mine drainage (AMD): causes, treatment and case studies. J Clean Prod 14:1139-1145

35. Schorscher HD, Shea ME (1992) The regional geology of the Poços de Caldas alkaline complex: mineralogy and geochemistry of selected nepheline syenites and phonolites. J Geochem Explor 45:25-51

36. Slavec GB, Mantovani MSM, Shukowsky W (2004) Estudo gravimétrico do maciço alcalino de Poços de Caldas. Revista Brasileira de Geociências 34(2):275-280

37. Raga DM (2009) Structural geology: an introduction to geometrical techniques, 4th edn. Cambridge University Press, Cambridge, p 632

38. Fossen $\mathrm{H}$ (2010) Structural geology. Cambridge University Press, Cambridge, p 463

39. Salamuni E (2016) Capítulo 8: Mapeamento e Reconhecimento de estruturas tectônicas, 2nd edn. In: Nadalin RJ (ed) Tópicos especiais em cartografia geológica. Oficina de Textos, São Paulo, pp 255-302

40. Dahlin T (2001) The development of DC resistivity imaging techniques. Comput Geosci 27:1019-1029

41. Kearey P, Brooks M, Hill I (2002) An introduction to geophysical exploration. Tradução de Maria Cristina Moreira Coelho, 1 st edn. São Paulo: Oficina de Textos, p 429

42. Milson J (2003) Field geophysics. Wiley, England, p 232

43. Telford WM, Geldart LP, Sheriff RE (1990) Applied geophysics. Cambridge University Press, New York, p 792

44. ABEM (2012) Terrameter LS-instruction manual. ABEM Instrument, Sundbyberg, $\mathrm{p} 122$

45. Geotomo Software (2003) Geoelectrical imaging 2-D \& 3D

46. Chulès JP, Delfiner $P(2012)$ Geostatistics_-modeling spatial uncertainty, 2nd edn. Wiley, Hoboken, p 726

47. Ellert R (1959) Contribuição à geologia do Maciço Alcalino de Poços de Caldas. São Paulo, Faculdade de Filosofia, Ciências e Letras-USP, Boletim 237. Geologia 18:5-63

48. Fonseca MJG, Silva ZCG, Campos DA, Torsatto P (1979) Texto explicativo. Carta geológica do Brasil ao Milionésimo. Folhas Rio de Janeiro, Vitória e Iguape (SF 23/SF 24 e SG 23), DNPM

49. Almeida FFM (1986) Distribuição regional e relações tectônicas do magmatismo Pós-Paleozóico do Brasil. Revista Brasileira de Geociências 16(4):325-349

50. Montes-Lauar CR, Pacca IG, Melfi AJ, Kawashita K (1995) Late Cretaceous alkaline complexes, southeastern Brazil: paleomagnetism and geochronology. Earth and Planet Sci Lett 134:4

51. Scudino PCB (1992) Caracterização hidrodinâmica do meio aquífero fraturado na área de Poços de Caldas e adjacências, mediante a análise do conteúdo radioisotópico das águas subterrâneas. Pós-graduação em Ciências e Técnicas Nucleares, Universidade Federal de Minas Gerais, Belo Horizonte, p 146

52. Dewandel B, Jeanpert J, Ladouche B, Join JL, Maréchal C (2017) Inferring the heterogeneity, transmissivity and hydraulic conductivity of crystalline aquifers from a detailed water-table map. J Hydrol 550:118-129

53. Cánovas CR, Macías F, Olías M (2018) Hydrogeochemical behavior of na anthropogenic mine aquifer: implications for potential remediation measures. Sci Total Environ 636:85-93

54. Waber N, Schorscher HD, Peters TJ (1992) Hydrothermal and supergene uranium mineralization at the Osamu Utsumi Mine, Poços de Caldas, Minas Gerais, Brazil. J Geochem Explor 45:53-112

55. Instituto de Pesquisas tecnológicas do Estado de São PauloIPT (1976) Estudo geológico-geotécnico preliminar para a aberturada cava da Mina do Cerrado-Poços de Caldas MG. Relatório 9.571 , vol 1, 2, 3

56. Alberti HLC (2017) Estudo hidroquímico e isotópico das águas subterrâneas impactadas pela drenagem ácida da Mina de urânio-Osamu Utsumi, Planalto de Poços de Caldas (MG). Ph.D. Thesis, Instituto de Geociências, Universidade Estadual de Campinas, Campinas, p 194

57. Wyllie DC, Mah CW (2004) Rock slope engineering: civil and mining, 4th edn. Taylor \& Francis, Routledge, p 431 
58. ISRM (1983) Na empirical failure criterion for rock masses. In: 5th ISRM congress, Melbourne, $\mathrm{p} 8$

59. Associação Brasileira de Geologia de Engenharia (1983) Métodos para descrição quantitativa de descontinuidades em maciços rochosos. São Paulo, ABGE. (Caderno Técnico), p 132

60. Cavalcanti SS, Sato HK, Lima OAL (2001) Geofísica elétrica na caracterização da hidrologia subterrânea na região do aterro metropolitano centro, Salvador, Bahia. Revista Brasileira de Geofísica 19(2):155-168

61. Silva RWC, Malagutti Filho W, Moreira CA (2009) Emprego do método da eletrorresistividade no estudo da contaminação subterrânea do cemitério municipal de Vila Rezende, Piracicaba, SP. Revista Brasileira de Geofísica 27:389-399

62. Moreira CA, Braga ACO, Fries M (2009) Degradação de resíduos e alterações na resistividade elétrica, $\mathrm{pH}$ e Eh. Revista Brasileira de Geofísica 27:283-293
63. Figueiredo WS, Nascimento CTC (2015) Soil electrical resistivity mapping in the Formosa city landfill, Goiás State, Brazil. Revista Brasileira de Geofísica 33:251-259

64. Kefeni KK, Msagati TAM, Mamba BB (2017) Acid Mine Drainage: prevention, treatment options, and resource recovery: a review. J Clean Prod 151:475-493

65. Skousen JG, Ziemkiewicz PF, McDonald LM (2018) Acid mine drainage formation, control and treatment: approaches and strategies. Extr Ind Soc 6:241-249

Publisher's Note Springer Nature remains neutral with regard to jurisdictional claims in published maps and institutional affiliations. 